\section{Maintaining peace across ethnic lines: new lessons from the past}

\section{Saumitra Jha}

$\mathrm{I}^{\mathrm{a}}$

$\mathrm{n}$ the year 1026, Mahmud of Ghazni led his cavalry down from the mountains of Afghanistan into the plains of India. His objective was the wealthy Hindu temple city of Somnath on the coast of Gujarat. Mahmud destroyed the temple and sacked the city, killing an untold number of the city's inhabitants. Ever since, Mahmud's raid on Somnath has been considered a pivotal event that polarized the Hindus and Muslims of India against one another. ${ }^{1}$

Yet little more than two centuries after the raid, the authorities of the re-built Somnath temple gave permission for a Muslim trader, Nur-ud-din Firuz of Hormuz, to found a mosque on temple lands. Hindu temple authorities actively encouraged Muslims to settle and trade near the temple, benefitting from the commercial taxes that Middle Eastern trade would bring. ${ }^{2}$ This mixed settlement of Hindus and Muslims still exists, although the Middle Eastern trade has long diminished and local merchants sell fish, not frankincense.

In fact, throughout India, towns that traded to the Middle East in medieval times continue to show evidence of increased tolerance between Hindus and Muslims. ${ }^{3}$ Because Hindus and Muslims in medieval ports had much to gain from exchange with one another, over the course of a millennium they developed a set of norms and organizations, or "institutions" that fostered between-group exchange. ${ }^{4}$ Many of these institutions continue to exist today, two centuries after the decline of Muslim-dominated Indian Ocean trade with the rise of European involvement. ${ }^{5}$ Instead of being repositories of Hindu-Muslim hatred, Somnath and other medieval port towns provide a long history of inter-ethnic tolerance that yield important lessons on how such hatreds may be overcome.

This article draws upon two studies, one empirical, one theoretical, to explore the lessons that medieval Indian Ocean trade provide for supporting ethnic tolerance in contemporary settings. ${ }^{6}$ It begins by sketching a theoretical framework to understand the incentives of agents to trade and engage in violence in ethnically-mixed regions. The article then shows how the theory fits the particular case of trade in the medieval Indian Ocean. Finally, the article draws lessons from the theory and India's institutional legacy to understand why ethnic tolerance fails and how tolerance may be fostered in contemporary settings.

The determinants of ethnic tolerance

At least as far back as Montesquieu in the 18th century, it has been argued that trade encourages "civility" between individuals, as loss of that trade renders conflict more costly. ${ }^{7}$ Yet looking at the repeated tension and violence between local populations and commercially-oriented ethnic minorities both throughout history and in many different settings around the world suggests a very

different story. From the Jews in medieval Western Europe to the Chinese in modern Indonesia and South Asians in modern East Africa, commercially-oriented ethnic minorities have often been targets of violence and expropriation. ${ }^{8}$ Why then did Muslim traders in medieval Indian ports enjoy an enduring environment of tolerance while many other commercial minorities did not? A theoretical model can shed light on this question and uncover broader strategies for supporting ethnic tolerance. ${ }^{9}$ The model focuses on towns with two types of ethnic groups, "local" and "non-local," where non-local ethnic groups differ from local groups by having (slightly) better outside options. In the case of Muslim traders in medieval India, the non-local group enjoyed social and cultural ties to Arabia and the Middle East not enjoyed by the local Hindu population. These made it easier for Muslim traders to leave and go elsewhere than for local Hindus, for whom investments, information, and social ties were also concentrated locally.

In the basic model, in each period individuals can choose to leave town, choose to trade a good that they produce, and choose targets for violence. Violence is destructive but can be used to seize a victim's property or to deter or punish particular actions. The capacity for violence is unevenly distributed, so that "strong individuals" (e.g., rulers or mob bosses) find violence cheaper and thus more profitable. The focus is on finding strategies that support "peaceful coexistence" over time: no one prefers to leave or to engage in violence with a member of a different ethnic group.

The model reveals that three conditions need to be satisfied to maintain peaceful coexistence over time. First, there needs to be "complementarity" between ethnic groups, i.e., there are gains from exchange between them. Second, there needs to a high cost for either group to steal or duplicate the source of the others' complementarity. Third, there needs to be an effective mechanism to redistribute the gains from trade between groups. ${ }^{10}$ It is useful to intuitively explain why these conditions are important for supporting peaceful coexistence.

The first condition for supporting peaceful coexistence is that there be complementarities, rather than competition, between groups. Consider the alternative case: members of different ethnic groups provide substitute goods or services that compete with each other. Then, a "strong" local (for whom violence is cheap) will have an incentive to target non-locals with ethnic violence. Violence against non-locals not only allows a strong local to seize their property but also to drive 


The greater the inter-group
complementarity, the more valuable
the presence of non-locals and the
lower the incentives for ethnic violence
- so long as the source of the
complementarity cannot be copied or
expropriated and the trade gains are
shared.

non-locals out and reduce competition. Weak non-local competitors are more attractive targets of violence than weak local competitors, as locals are harder to drive out of town: they essentially have nowhere else to go. ${ }^{11}$ Thus societies where local and non-local ethnic groups compete are likely to exhibit greater ethnic violence.

In contrast, when ethnic groups provide complementary goods or services to one another, the incentive to attack non-locals diminishes. If non-locals leave as a response to violence, locals will face reduced supply and higher prices for goods that only non-locals can provide. The greater the inter-group complementarity, the more valuable the presence of non-locals and the lower the incentives for ethnic violence.

Complementarities between ethnic groups that live in close geographical proximity are difficult to maintain over time, however. If non-locals provide valuable services to locals then, over long time horizons, members of the local group will have incentives to replicate their production processes, or simply to violently seize the means of producing that complementary good. Thus a second condition for supporting peaceful coexistence over time is that the sources of ethnic complementarity be costly to replicate or expropriate.

Yet even this robust inter-group complementarity will not be sufficient for ensuring peaceful coexistence. When non-locals constitute a minority and provide a complementary good or service, the restricted supply of that service lead non-locals to enjoy high relative prices, and potentially even monopoly power. The resulting wealth inequalities between locals and non-locals lead to incentives by strong locals to target non-locals with violence to seize wealth and property. Thus a third condition to support peaceful coexistence is the need for an effective mechanism to redistribute the gains from trade.

Although a mechanism to redistribute the gains from trade from members of a non-local ethnic group to the local population is desirable for peaceful coexistence, it may fail to occur for two reasons. First, there is a public goods problem: the benefit of reduced incentives for ethnic violence is shared by all, but each individual would prefer that others pay. Thus there is a temptation for each individual to take advantage of others' contributions while reducing the amount they themselves provide. Thus redistributive transfers will be under-supplied in general. Second, what transfers do occur will be from rich non-locals to a particular set of locals: the strong (often incumbent political elites), as these have the lowest costs of engaging in violence. In fact, these transfers of protection money to rulers by non-local ethnic groups, sometimes called "ethnic cronyism," may actually provide perverse incentives for rulers to intermittently allow ethnic violence by poorer locals in order to extract greater transfers from non-local minorities. These sub-optimal outcomes can be improved upon by the introduction of explicit mechanisms to share the gains from trade with the broader local population.

\section{An example: religious tolerance in medieval India}

Medieval Muslim traders in Indian ports were fortunate to benefit from a natura means to share the gains from trade that allowed them to satisfy all three conditions without requiring the creation of an explicit redistribution mechanism. ${ }^{12}$ First, Muslim traders provided complements to Hindu producers and financiers: access to the trade networks and markets of the Middle East. Second, because Muslim trade networks were coordinated along pilgrimage routes that were specific to Islam - such as the Hajj - they were largely closed to Hindus and could not be stolen or replicated. Third, Muslim traders benefitted from an inherent redistribution mechanism: Middle Eastern trade was relatively easy for any Muslim to access. With pilgrimage routes coordinating where and when trade would occur, Muslims did not require personal ties or information to enter into trade. ${ }^{13}$ This ease of entry for Muslims meant that competing groups of both immigrants and converts became traders whenever Indian prices were high. Such entry increased competition within the non-local minority and improved prices for locals. This natural mechanism of redistribution thus reduced incentives for locals to attack Muslims to seize wealth.

Over ten centuries of trade, Hindus and Muslims in overseas trading ports developed sets of norms and organizations that bolstered these incentives so that peaceful coexistence could be maintained even with adverse changes, such as times of famine or scarcity. ${ }^{14}$ It is these institutions that persisted even after Muslims lost their advantages in trade following increased European involvement, and facilitated a continued legacy of religious tolerance. ${ }^{15}$ Although the institutions themselves differed among medieval ports, the underlying economic logic was fairly consistent and provide useful lessons for current policy aimed at peaceful coexistence. One set of institutions bolstered complementarities and opportunities for exchange between groups, while the other provided supplemental mechanisms to make explicit transfers of the gains from trade from non-locals to locals.

Complementarities and opportunities for between-group exchange were raised through a variety of means. First, medieval ports developed institutions to encourage different ethnic groups to specialize and punish the replication of others' complementarity. One example was that of "Kaala-paani" (literally "black water") a community norm that punished Hindus who traded across the ocean with loss of caste and ostracism. Second, Hindus and Muslims in some ports developed joint guild organizations that jointly fostered overseas commerce and future complementary endeavors. Third, Hindus and Muslims developed norms that fostered increased between-group interaction in social as well as economic spheres that raised the 
opportunities for future interactions. These included a norm of joint celebrations of religious and other festivals. A second set of institutions supported the mechanism of redistributing the gains from trade, both by encouraging Muslim immigration and conversion, but also through explicit transfers. Hindus were relatively more tolerant of conversion to Islam and the establishment of mosques in medieval ports than other Hindu-ruled towns. ${ }^{16}$ Muslims, for their part, contributed taxes on commerce to Hindu temples, and in some cases explicitly endowed Hindu temples themselves. ${ }^{17}$

\section{Maintaining tolerance in other settings}

The logic underlying peaceful coexistence between Hindus and Muslims in medieval ports and the supporting institutions that emerged can be readily applied to other historical and contemporary settings where non-local and local ethnic groups coexist, both to understand why ethnic tolerance failed and how tolerance may be fostered. The model suggests that ethnic violence is likely to occur when ethnic groups compete, when the source of inter-ethnic complementarity is easy for one group to expropriate or replicate, or when no mechanism exists to redistribute the gains from trade.

\section{Being impossible to violently expropriate, specialized skills do provide a better basis for inter-ethnic complementarity and tolerance than "hard" assets such as land, machines, or other forms of physical capital.}

Competition between locals and immigrant groups for jobs has often been cited as a reason for ethnic tension. ${ }^{18}$ The theory suggests that these tensions are most likely to arise in jobs that are unspecialized and require either few or generally-available skills or inputs, since these are the least costly to enter. Yet even non-local minorities who do not compete, but enjoy complementarities that stem from tangible assets, such as land, machines, or other forms of physical capital, will face violence. These assets can be seized by strong locals, as white farmers in Zimbabwe discovered in the late 20th century.

Being impossible to violently expropriate, specialized skills do provide a better basis for inter-ethnic complementarity and tolerance, but even these can be replicated in the longer term. Minorities that have specialized skills can become increasingly attractive targets of violence if locals become able to duplicate those skills. The forced expulsion of Jews from Spain at the end of the 15th century was precipitated in part by prior conversions, both forced and voluntary, of Jews to Christianity. These "new" Christians provided the administrative skills to Spanish rulers for which they previously depended on the better-educated Jewish population. ${ }^{19}$ It is possible that the expansion of public education in Western Europe and the United States may also have had the unfortunate side-effect of raising the likelihood of violence against educated minority incumbents in skilled jobs by rendering them more replaceable by locals.
In contrast to physical and human capital, most ethnic trading networks are both difficult to steal - being intangible - and extremely costly to replicate. Because there are network externalities - the value of a trading network increases with the size of its membership - there will be high costs for any local to invest in a set of personal exchange relationships that would attain the scale necessary to compete with an ethnic trading network. Thus non-locals can use the privileged access to goods and services from ethnic ties elsewhere to provide the basis for sustained complementarity in mixed communities.

Like Muslim traders in medieval Indian ports, Sephardic Jews benefitted from valuable trading networks in the 15 th and 16 th centuries that rendered them welcome arrivals in Ottoman ports in the Mediterranean. With links to Spain and the Atlantic economy, their immigration was actively encouraged by local Ottoman authorities, and the city of Salonica in particular attracted a large number of Jewish refugees. A combination of permissive immigration and religious specialization resulted in a long history of peaceful ethnic coexistence. ${ }^{20}$ For the next four centuries, Ottoman Salonica, sometimes referred to as the "Mother of Israel," maintained a remarkable degree of ethnic tolerance, with Jews specialized in commerce. ${ }^{21}$

While the trading networks of the Chinese in modern Indonesia and South Asians in modern East Africa also made them valuable to the local population, these groups lacked a general mechanism of redistribution. Chinese and South Asian ethnic trading networks, based upon personal and community ties, were closed to competitors, and thus relatively small minority groups were able to capture much of the gains from trade. This rendered these minorities increasingly attractive targets for ethnic violence and susceptible to expropriation by strong locals. ${ }^{22}$

One ethnic trading network, however, is remarkable in its relative success at maintaining peaceful and profitable coexistence with local populations in East Africa and elsewhere. The Nizari Ismailis, followers of the Aga Khan, have developed systematic mechanisms of explicit philanthropy that benefit the local population, including the provision of public goods, such as hospitals and schools, as well as organizations that explicitly match Ismailis and locals in joint business ventures. ${ }^{23}$ These mechanisms also often include commitments not to engage in corrupt practices that foster "ethnic cronyism." Although the Ismaili case is unusual in its level of organization, it suggests that minority communities, acting on their own initiative, may benefit from organizing explicit transfers and public goods provision.

\section{Conclusions}

In medieval Indian ports, Hindus and Muslims developed institutions that continue to support ethnic tolerance today. These institutions provide insights into how policymakers can encourage peaceful coexistence across ethnic lines. To encourage tolerance, methods that have been employed in medieval ports include the encouragement of specialization within groups, the fostering of opportunities for 
repeated interaction in both economic and non-economic spheres, and the creation of institutionalized mechanisms to allow the sharing of the gains from trade.

All of these approaches may yield dividends for ethnic tolerance today. Educational systems that allow minority individuals the choice of leveraging the advantages of their group to engage in broader exchange, rather than promoting homogenization of a town's human capital, may result in less competition and greater inter-group complementarity. An explicit and well-publicized system of transfers established by members of a minority community to the local population, in the form of earmarked taxes or endowed public goods, may be effective in improving between-group relations. Another mechanism that has enjoyed success in aligning incentives is to provide equity shares in trading ventures to the local population. ${ }^{24}$ Organizations that match members of different communities with complementary skills in the creation of such jointly-held business ventures may combine the benefits of complementarity with transfer provision. Trading networks may have afforded minority groups an important source of comparative advantage that rendered them valuable neighbors. Long after the decline of Indian Ocean trade, it may be that we can apply some of their institutional learning to the fostering of inter-ethnic peace today.

\section{Note}

Saumitra Jha is an Academy Scholar at Harvard University. This work draws on the author's Ph.D. dissertation in economics at Stanford University. The author owes particular thanks to Susan Athey and Avner Greif for insights and criticism. Please direct comments to sjha@wcfia.harvard.edu.

\section{Alberuni (1030); Thapar (2004).}

2. Thapar (2004).

3. Jha (2007c).

4. Greif (2005).

5. Jha (2007c).

6. Jha (2007b; 2007c).

7. Hirschman (1977).

8. Benbassa and Rodrigue (2000); Chua (2003).
9. Jha (2007b).

10. Jha $(2007 b ; 2007 c)$.

11. For a different explanation for why ethnic violence is more likely to happen than class violence, see Esteban and Ray (2007).

12. Jha (2007c).

13. di Verthema (1503); Lombard (2000).

14. See Greif and Laitin (2004) for a general theory of institutional persistence.

15. Jha (2007c).

16. al Malibari (1528).

17. Bayly (1989); Thapar (2004); Jha (2007c).

18. Olzak (1992)

19. Benbassa and Rodrigue (2000).

20. Benbassa and Rodrigue (2000). A less attractive aspect of ethnic specialization in the Ottoman empire was that it was strictly enforced by the state.

21. Mazower (2005).

22. Landa (1994); Chua (2003).

23. Penrad (2000).

24. Jha (2007a).

\section{References}

al Malibari, Z. a.-D. 1528 [1833]. Tohfut-ul-mujahideen. translated from the Arabic by M.J. Rowlandson. London: Oriental Translation Fund of Great Britain.

Alberuni, A.-R. M. I. A. 1030 [2005], Indica. Edited by E.C. Sachau. Delhi: Munshiram Manoharlal.

Bayly, S. 1989. Saints, Goddesses and Kings: Muslims and Christians in South Indian Society 1700-1900. Cambridge, UK: Cambridge University Press. 
Benbassa, E. and A. Rodrigue. 2000. Sephardi Jewry: A History of the JudeoSpanish Community, 14th-20th Centuries. Berkeley, CA: University of California Press.

Chua, A. 2003. World on Fire: How Exporting free Market Democracy Breeds Ethnic Hatred and Global Instability. New York: Doubleday.

di Verthema, L. 1503 [1576]. The Navigation and Voyages of Lewes Vertomannus, Gentleman to the Citie of Rome. Tr. from the Latin by R. Eden. Hakluyt.

Esteban, J. and D. Ray. 2007. “On the Salience of Ethnic Conflict.” Working paper. Deparment of Economics. New York University. www.econ.nyu.edu/user/debraj/Papers/EstebanRaySalience.pdf.

Greif, A. 2005. Institutions and the Path to the Modern Economy: Lessons from Medieval Trade. Cambridge, MA: Cambridge University Press.

Greif, A. and D.D. Laitin. 2004. "A Theory of Endogenous Institutional Change." American Political Science Review, Vol. 98, No. 4, pp. 633-652.

Hirschman, A. O. 1977. The Passions and the Interests: Political Arguments for Capitalism before its Triumph. Princeton, NJ: Princeton University Press.

Jha, S. 2007a. "Shareholding, Coalition Formation and Political Development: Evidence from 17th Century England." Working paper. Harvard University.

Jha, S. 2007b. “A Theory of Ethnic Tolerance.” Working paper. Harvard University.

Jha, S. 2007c. "Trade, Institutions and Religious Tolerance: Evidence from India." Working paper. Harvard University. www.fas.harvard.edu/ jha/Jhatradetolerance.pdf.

Landa, J. T. 1994. Trust, Ethnicity and Identity: Beyond the Institutional Economics of Ethnic Trading Networks, Contract Law and Gift-Exchange. Ann Arbor, MI: University of Michigan Press.

Lombard, D. 2000. "Introduction," in D. Lombard and J. Aubin, eds. Asian Merchants and Businessmen in the Indian Ocean and the China Sea. New Delhi: Oxford University Press.

Lombard, D. and J. Aubin, eds. 2000. Asian Merchants and Businessmen in the Indian Ocean and the China Sea. New Delhi: Oxford University Press.

Mazower, M. 2005. Salonica, City of Ghosts. New York: Alfred A. Knopf.

Olzak, S. 1992. The Dynamics of Ethnic Competition and Conflict. Stanford, CA: Stanford University Press.

Penrad, J.-C. 2000. "The Ismaili Presence in East Africa: A Note on its Commercial History and Community Organization," pp. 223-238 in D. Lombard and J. Aubin, eds. Asian Merchants and Businessmen in the Indian Ocean and the China Sea. New Delhi: Oxford University Press.

Thapar, R. 2004. Somanatha: The Many Voices of a History. New Delhi: Penguin. 